\title{
14 Political, Corporate, and Ritual Economic Processes of Early Historic South Asia
}

\section{Introduction}

This chapter explains the economic profile of early South Asia by framing production, consumption, and distribution within their sociopolitical contexts. Here, I emphasize the importance of the plurality of social-political and religious agencies, discuss the interaction between various actors, and explore various strategies of interaction as the stimulants of both economic changes and the development of networks.

Interaction through the coordination and counterbalancing of the economic impacts of various actors led to economic change and development in the period between 300 BCE and 300 CE. Broadly, economic development is visible in the processes of production and connectivity. An increase in production (and possibly productivity) is indicated by reliance on specialized methods of irrigation that increased production, especially of commercial agricultural goods; the presence of a greater variety of specialized crafting associations; the volume of ceramics found in excavation; and intensive monetization of various regions. Indices for increased connectivity of early historic South Asia are the increased number and greater size of urban settlements; development of ports alongside their regional hinterland and satellite settlements; and more intense use of particular corridors and highways due to the intensive commercial and social travel by both inland and sea routes.

Owing to regional diversity in terms of physical geography, the nature of polities, and social norms, the changes just outlined were neither uniform nor occurred at the same pace throughout the subcontinent. Similarly, the indices of economic changes differ in intensity as well as extent. For example, the history and development of cities and their satellite settlements in the northern alluvial plain differed from that in parts of the Deccan plateau and the Western Ghats. Similarly, the monetary practices of the northern and western regions were different from those in the economies of the south in terms of the intensity of circulation of locally produced coins.

While great regional difference was undeniable, we must also be mindful of the diversity of source material available to us. At times, the sources allow deep insights into specific economic processes and developments, while they remain silent on many issues. It is, therefore, impossible to work out a general narrative of the economy of early historic India as a whole. This is not a problem of the quantity of source material, which is rich and abundant. We have both indigenous and for-

\footnotetext{
- Open Access. (C) 2022 Mamta Dwivedi, published by De Gruyter. (c) BY-NC-ND This work is licensed under the Creative Commons Attribution-NonCommercial-NoDerivatives 4.0 License. 
eign literary accounts, epigraphic records, and numismatic and material remains. ${ }^{1}$ However, the sources present particular challenges in terms of their composition and how they may be brought to bear on the larger picture. First, most of the literary sources available to us are normative, narrative, and canonical in nature. They are composite texts, and their compilation dates span centuries. Second, the Arthaśāstra, which is almost indispensable for gaining insights into economic and administrative practices, develops a state-driven scenario that is idealized and likely informed by the observation of a localized center with a relatively strong political and economic integration. Third, archaeological excavations have long been guided by textual studies. Finding urban centers mentioned in the texts was their main purpose, be this the search for Roman emporia along the western and eastern coasts, sites of Buddhist significance, or cities mentioned in the kāvya literature, the Maha $\bar{a}$ bhārata and the Rāmāyana. ${ }^{2}$ Many sites, moreover, have experienced continuous occupation. Horizontal excavation and broad surveys have been rare, limiting the study of urban settlements and their function within the regions. Additionally, and related to the previous, is the limitation of the numismatic record. Coin finds are usually connected to sites through surface finds of hoards or in stūpa deposits, but rarely in stratigraphic contexts. This limits the chance of studying their role in wider economic contexts and developments. These limitations prevent us from developing a general model of processes in more than their broadest outlines.

However, sketching aspects of economic processes in the past need not require neat, flawless pictures. Therefore, this chapter is an attempt to understand economic behavior in various contextual scenarios without flattening regional particularities or silencing gaps in our knowledge. I shall first identify how the interaction of different social, religious, and political actors created favorable conditions for economic development in early India. Here, I identify three categories of catalysts at the social, religious, and political level: ethno-social stimulants and private associations; the rise of monastic religion; and imperial aspirations of various local polities. I shall then discuss the most important indices of economic change and how they might be related to what I have identified as the catalysts of change. This is followed by a section about changes in different sectors, such as the production and distribution of agricultural and artisanal goods; the greater connectivity of routes and urban settlements; and last but not least, an increase in elite and sub-elite consumption visible in the circulation of particular goods. In the final section, I discuss distribution and markets and the role of different actors facilitating the movement of people and goods, which shaped the connectivity in early India.

1 For the discussion of sources, see Dwivedi, vol. 1, ch. 10.A; von Reden, vol. 1, ch. 10.B.

2 For a discussion on beginning of archaeological and antiquarian studies in India, see Dwivedi, vol. 1, ch. 15. 


\section{Stimulants of the Economy}

There are various political and social stimuli that shape and characterize the economy. In the context of our region and time, there are political and social actors who operated within various institutions to reach their sociopolitical goals. This section identifies such political, social, and religious institutions and their role as catalysts of economic change and development, and most importantly, of the establishment of coordinated networks of transport and communication.

\section{II.1 Ethnosocial Stimulants and Private Associations}

The ethnosocial structure of society characterized the economic profile of early South Asia, and can be explained by two examples: first, the prevalence of dedicated labor groups in the socioritual organization of the society, which appear to be more prominent in the alluvial regions of the northern plains; and second, the formation and functioning of professional associations. These characteristics were embedded in two essential institutions of early India, private ownership of land and private entrepreneurship.

\section{II.1.1 Occupational Groups and Labor Regimes}

A particular feature of Indic society was its stratification into four socioritual groups, called the varnas. ${ }^{3}$ In normative texts, these are also occupational groups with certain recommendations and restrictions for each social group. Even though there are various instances suggesting individual flexibility, a large part of physical labor in agricultural and domestic context was provided by the Sudras (the lowest social classes). Even though the presence of institutionalized slavery in ancient India is a debated topic, we find mentions of people being reduced to the state of $d \bar{a} s a$, which has ambiguous connotation of either being a paid servant or a slave. The evidence indicates the use of a large number of $d \bar{a} s a s$ as laborers mainly in the context of royal palaces and monasteries. ${ }^{4}$ Surprisingly, we do not have evidence for the use of dāsas as agricultural labor. The Arthaśāstra recommends keeping agriculture free from the use of forced labor. ${ }^{5}$ Rather, it envisions two types of pro-

3 The four groups are Brāhmaṇa (teachers and priests), Kṣatriya (rulers and soldiers), Vaișya (merchants, businessmen and agriculturists), Sudras (craftsmen and servant groups).

4 For a discussion, see Dwivedi, ch. 5, III, this volume.

5 Forced labor, punishment, over-taxation, and animal herds are considered bad for the agriculture by Kauṭilya, see Kauțilìya Arthaśāstra (KA) 6. 1. 10. However, labor of slaves and men paying their fines through manual labor are to be used during sowing of the fields, see KA 2. 24. 2 . 
ducers, small landowners working their own fields and tenants working on private or large royal holdings. Private land owners are typically organized in households and till their land with the help of seasonal wage labor. ${ }^{6}$ Land belonging to the king (sìtā), by contrast, is farmed in a system of sharecropping; ${ }^{7}$ tenancies could be cancelled in case the tenants failed to cultivate and could be transferred to another who was willing to cultivate. ${ }^{8}$ Sharecropping was perhaps not altogether absent in nonstate contexts either, as we have epigraphical evidence for rich absentee landlords and monasteries as beneficiaries of agricultural land which they hardly cultivated themselves. According to the Arthaśāstra, moreover, the state created incentives for the expansion of agriculture by offering tax exemptions, rebates, and even loans to farmers willing to bring virgin land under cultivation. ${ }^{9}$ From the third century BCE onward there is a noticeable increase in the compilation of legal treatises (dharmaśāstras) defining terms of ownership and division of private property, which may indicate the increasing importance of private ownership in this period. ${ }^{10}$

\section{II.1.2 Professional Associations and Corporate Bodies}

The second feature is the prevalence of professional associations and corporate bodies, often called guilds (śreni and negama/nigama). ${ }^{11}$ We learn of different types of associations in a wide range of occupational contexts ranging from flower merchants to weavers, ivory carvers, traders, and even mercenaries. ${ }^{12}$ Economic security of both the members of the associations and their clients was perhaps the main reason for the formation of these guilds. Corporations and associations of any kind and size were of great economic consequences, as they provided security for their members against individual loss and misfortune, and allowed them to share various kinds of risks. ${ }^{13}$ The importance of associations can be seen in the enormous role they played in long-distance trade and travel, and the fact that they survived political change. Moreover, many associations were wealthy institutions using their as-

6 For more on the constitution of an agrarian household, see Dwivedi, ch. 5, II, this volume.

7 We find reference to ardhasitika, which is differently translated as 'tiller tenants' and/or 'sharecroppers' for half the share of the produce. There are other tenants too who get to keep one-fourth or one-fifth of the share depending on the type of crop and land. See KA 3. 11. 23; 2. 24. 16-18.

$8 K A$ 2. 1. 10.

9 KA 2. 2. 30; 2. 1. 86; 3. 9. 33. See also Mital 1995, 84-85.

10 For a discussion on laws, see Dwivedi, ch. 10, IV, this volume.

11 For a detailed discussion on corporate bodies, see Dwivedi, ch. 5, V.2, this volume.

12 For examples of epigraphic references to guilds, see Mirashi 1981, pt. 1, 95-100; Thakur 1987,

73. For mercenary guilds or corporate troops (bhrtabala and śreniibala), KA 7. 8. 27; 9. 2. 1, 4. For the economic role of armies, see Dwivedi, ch. 5, IX, this volume.

13 The guilds may have assumed the liabilities for the deposit of raw material or cash in case of death. Being a part of a guild also enabled the members to accept deposits, see KA 4. 1. 1-4. 
sets for moneylending, which influenced the development of credit and banking. ${ }^{14}$ The economic potential of these corporate bodies can also be seen when one looks at monetary donations as 'perpetual endowments' (akșayanivi) made to them, with an agreement that a percent of profit shall be donated to a dedicated monastery every month (also below, II.2.1).

Regarding the internal functioning of guilds, we have little information. The śreșthi was probably the head of the association, but the term can also have the connotation of rich merchant, financier, and banker. ${ }^{15}$ The size of corporate organizations also varied. Though there were profession-based organizations within villages, it also seems possible that settlements and even cities formed parts of a corporate body with administrative functions. ${ }^{16}$ Seals and coins bearing the term nigama/negama/nekama have been found at various sites. These have been interpreted as closed currency systems or even insignia of corporate or civic bodies. ${ }^{17}$

\section{II.2 Monastic Institutions as Financial Magnates}

The emergence of an elaborate ritual and social network associated with the rise of monastic Buddhism was an important socioeconomic phenomenon. A large number of Buddhist sites situated along the inland trade routes, riverine ports, and other urban settlements exhibit the commercial connections and coordination of mercantile networks. Buddhist monasteries acted as an economic stimulant in two fundamental ways: as repositories of wealth and credit institutions, and as centers of urban innovations.

\section{II.2.1 Rise of Monasteries as Repositories of Wealth and Credit Institutions}

From the second century BCE onward, Buddhist monasteries had become recipients of dāna, donations for merit, in the form of goods and money. Apart from individuals making donations, commissioning sculptures, and constructing cave dwellings for the monks, there were large monetary deposits to assure the monasteries had a

\footnotetext{
14 The head of a guild was called śreșţi, which also has the connotation of banker in Sanskrit. There are references to guilds or the heads of the guilds is found commonly in the literary sources. Various dharmaśāstras and the Kauțilya Arthaśāstra establish the rate of interest at which the loans are to be given. See Mishra 1992, 53-58; Evers 2017, 167-168.

15 There are variants to the term śreșțhin (Skt.), such as sețțhi (Prakrit), and sreṭhi (Gāndhārī). A Gāndhārī birch bark manuscript from Afghanistan, dated between 1-100 CE, refers to srețiputra. Baums and Glass 2002, search word "srețhi." See more about sețthi as a local economic elite in Dwivedi, ch. 5, IV, this volume.

16 The reference here is to the nigama type of corporate bodies, Thakur 1987.

17 Thakur 1987; Ray 2010.
} 
sustained income. First, kings seem to have made donations of tax income from certain villages and reallocated customs collected at ports. Then, from the first century onward, there were also 'perpetual endowments' (akșayanivī) that associations or guilds received on behalf of a monastery with an agreement for paying a certain portion of their profits to the monastery at regular intervals. ${ }^{18}$

The close associations among Buddhist monasteries, merchant groups, and guilds has been emphasized frequently. There are numerous references to monks and merchants travelling together by land and sea. ${ }^{19}$ The close connection between associations and monasteries is perhaps also a reason for monasteries developing into credit institutions. Schopen has explained the development of formula for written credit notes and contracts in Buddhist contexts in much detail. He has shown that monasteries, at least of the Mūlasarvastivādi tradition, accounted for their wealth by separating what would be stored in the inner treasury or depository (koșthikā), with a portion kept aside for the maintenance of monastery and for lending. ${ }^{20}$ The Mūlasarvastivāda-vinaya, citing the Buddha, also recommends lending at interest and the fixing of the loan in writing to avoid situations of nonpayment. A written contract should be drawn up that included the date of the agreement, the lender and the borrower, the "property" lent out, and the interest to be paid. The contract should be sealed and witnessed:

The Blessed One said: "Taking a pledge (ädhilbandhaka) of twice the value (dviguna), and writing out a contract (likhita) that has a seal and is witnessed (sākșimat), the perpetuity is to be placed. In the contract the year, the month, the day, the name of the Elder of the Community (samghasthavira), the Provost of the monastery (upadhivärika), the borrower, the property, and the interest (vrddhi) should be recorded."21

Possibly, monasteries adopted written contractual forms from Greek models, but they also adapted them to their own tradition of contracting transactions orally. ${ }^{22}$ Yet by adopting the written form for formulaic credit notes and contracts in their daily business, monastic communities greatly contributed to, or even initiated, greater security in credit transactions, and most likely greater volumes of them. ${ }^{23}$

\section{II.2.2 Monasteries as Centers of Technological Innovation and Dissemination}

As wealthy participants in growing economies, monasteries participated in technological innovations, both in a narrower and wider sense, and both actively and pas-

18 See Dwivedi, ch. 5, VII.2, this volume.

19 A Chinese pilgrim, Faxian, visited India in $399 \mathrm{CE}$ and took a mercantile ship on his way back to China. He reports having taken a ship from Tamralipti to Sri Lanka and from Sri Lanka to China through Southeast Asia, Sen 2006, 25-26.

20 Schopen 2004, 48-51.

21 The Vinayavibhanga of the Mūlasarvāsrivāda-vinaya vide Schopen 2004, 49.

22 See also sec. II.3.2 for the Greek influence on Indic practices.

23 Schopen 2004, 45-90. 
sively. A large number of monumental remains of Buddhist institutions show their use of new building materials and artistic styles. Monastic complexes consisted of stūpas (apsidal shrines consisting of relics of the Buddha), caityas (prayer halls), and vihära (residence complex for monks and nuns). Most important is the evidence for the use of burnt bricks in the construction of the buildings and the advanced masonry in the often elaborate architectural structures. They were embellished with carvings and sculptures depicting life of the Buddha and different Bodhisattvas (potential Buddhas). ${ }^{24}$ The importance of Buddhist architecture can be taken from the fact that no other institution or organization in the early historic period has left such conspicuous and elaborate monumental remains. Most of what is studied as early historic art comes from monastic complexes.

There is, moreover, a notable involvement of Buddhist monasteries in hydraulic engineering. Evidence of monastic waterworks is mainly of two kinds: aqueduct channels within monastic complexes, and tanks for water storage. A particularly close relationship between Buddhist monastic sites and irrigated agriculture and horticulture has been found in the area around Sanchi. ${ }^{25}$ The development of irrigated agriculture may have been related to the key role Buddhist organizations played in the commercial farming and trade of cotton in the western Deccan. ${ }^{26}$

As centers of education, monasteries also participated in the dissemination of written culture and writing materials. From the first century onward, a large number of Buddhist manuscripts on birch bark shows that writing was an important and desirable skill that was encouraged and spread by monasteries. ${ }^{27}$ By issuing written credit notes and contracts in their dealings, they also disseminated the use of literacy for new purposes. ${ }^{28}$

\section{II.3 Political Stimulants: Imperial Aspirations of States}

The changes and development in the political economy of early India was marked by two phenomena: the emergence of regional imperializing states, and the steady intervention and influences of political powers from the northwestern regions of the subcontinent. Both shaped the fiscal institutions, monetary profile, and development of religious institutions in the subcontinent. Local and external political processes were not mutually exclusive, but rather cumulative in nature.

24 See also Dwivedi, ch. 5, VII; Morris, ch. 13, IV.3, this volume.

25 For a detailed discussion on involvement of Buddhist monastic centers with development in hydraulic infrastructure, see Dwivedi, ch. 10, VI.1, this volume. Also see Shaw 2007; 2018.

26 Brancaccio 2018.

27 Skilling 2008, 61.

28 Schopen 2004, 45-90. 


\section{II.3.1 The Impact of the Mauryan Dynasty}

The Indo-Gangetic plains of the subcontinent experienced the earliest of the expansionist states, where the earliest of the territorial polities called janapada, were merged to form sixteen 'greater' territorial polities (mahājanapada) during the sixth and fifth centuries BCE. The sixteen mahäjanapadas were monarchical in nature. Around the fourth century вСE, one of the mahäjanapadas, Magadha, had emerged as the dominant political center of northern India under the Nanda dynasty usurped by the Maurya dynasty at the end of the fourth century BCE. The founder of the Maurya dynasty, Candragupta Maurya, had unified the north under his political supremacy and established the western boundary of his empire under the famous Treaty of Indus (ca. 303 BCE) with Seleukos. ${ }^{29}$ Under his successors, especially his grandson Aśoka, a large part of the subcontinent was brought under Mauryan rule. The pan-Indian presence of Aśokan edicts, except in the deep south, is indicative not just of the spread of his moral teaching, but also of the consolidation of networks of communication that were necessary for the spread of an imperial ideology. Arguably, the possibility of establishing a functional network of administration and resource appropriation was also the background of the Arthaśāstra. The establishment of various offices responsible for the upkeep of channels of communication, the gathering of relevant information about resources within the domain, and the maintenance of records are also known from various epigraphic sources. ${ }^{30}$

The Mauryan political system is usually regarded as the first empire in South Asia. Some scholars regard the imperial experience as a stimulus for state formation in the Deccan and deep south. This is a questionable approach that posits a hierarchical model of state formation and political evolution leading to derivative state structures. ${ }^{31}$ However, from an economic perspective, the growth of urbanism, monetization, and spread of pottery from the third and second centuries BCE onward shows the enormous economic dynamics set in motion by the greater connectivity of the subcontinent in the course of the Mauryan period.

\section{II.3.2 Influences from the Northwest}

The northwestern region has been considered a crossroad, leading to the presence of mutual sociopolitical influences from different cultures including Greek, Iranian, Central Asian, and Indian. Leaving Indo-Buddhist influences in Central Asia and Iran aside, scholars have emphasized Hellenistic influences above all in northwestern India in different spheres, ranging from cultural and political to monetary and

29 Von Reden, vol. 1, ch. 1, 25.

30 For an overview of the fiscal system, see Dwivedi, ch. 10, II, this volume.

31 Dwivedi, vol. 1, ch. 3; ch. 15. 
technological. Hellenistic influence is quite noticeable in various sculptural representations in Buddhist art in the northwest. Under the western polities, like the Indo-Greeks, Scythians, and subsequently also the Kuṣānas, the Buddhist monastic religion continued to flourish. Some scholars attribute this to the continued practice of royal patronage under most of the political powers active in northwest India, while others argue for the role of local elites who patronized Buddhism, contributing to the rise of monasteries as centers of wealth. ${ }^{32}$ Politically, a large degree of imperial coevolution has been emphasized, leading to the growth of diplomacy, routes of connections, and defense structures that both secured borders and relationships between the Hellenistic and Indian polities. ${ }^{33}$

The northwestern region also experienced a complex monetary scenario where the Indic monetary denomination, kārșāpaṇa, and the Greek coinage cocirculated. ${ }^{34}$ Greek coins spread as far as Barygaza, where their circulation was still attested in the first century CE. ${ }^{35}$ The northwest emerged as a multilingual region where bilingual and biscriptual coins circulated for several centuries. The practice of placing portraits of rulers on coins became widespread in northern India with the expansion of the Indo-Greek kings into the northwestern regions. Such iconography was clearly used a political statement in the rivalries between the Sakas and Sātavahānas, for example when Gautamīputra Sātkarṇi counterstruck Nahāpana's coin after defeating Nahāpana in the early first century CE. Moreover, the standard of the gold dināras introduced into the subcontinent by the Kuṣānas continued to be used by polities even long after the decline of the Kuṣāṇas.

As indicated above, the practice of written debt notes and contracts is sometimes thought to have resulted from Greek influence in the northwestern regions, as did more standardized methods of written recordkeeping. There is no direct evidence for this influence, but the fact that such tools are first attested in the northwestern regions, while oral contracts and oaths remained more widespread in the south, might suggest that cultural interaction was a fertile breeding ground for their local development.

\section{Indices of Economic Change}

In this section I will look, in more detail, at specific forms and indices of economic development, as can be seen in an increase in agricultural and craft production,

32 Fussman 2015. See also Morris, ch. 4, IV.2; ch. 13, III.2; this volume.

33 Apart from the numerous accounts of a more colonial kind, see the nuances brought forward by Kosmin 2014, 31-78.

34 See also Dwivedi, ch. 10, III, this volume; Morris, ch. 9, II.3, this volume.

35 Periplus Maris Erythraei (PME) 47. Memories of Greek presence in the region remained strong, according to this passage. 
expansion of settlements, greater connectivity between regions, and complex processes of monetization in the subcontinent.

\section{III.1 Agricultural Development: Hydrological Advancements and Regional Strategies}

In early historic South Asia, a greater variety of grain crops was cultivated than in any contemporary world region. This is owed to the long tradition of local domestication of wild plants and their adoption from other regions since the third and second millennia все. ${ }^{36}$ Many vegetables and fruits were domesticated still during the early historic phase. ${ }^{37}$ Many crops, moreover, were cultivated in year-round agricultural cycles, or underwent 'double cropping,' referring to the cultivation of both winter and summer crops. Rice, millet, mustard, sesame, cotton, hemp, and some pulses formed the main crops of the summer cultivation cycle irrigated by the monsoon rain from July to August. Winter crops included wheat, barley, flax, safflower, and a variety of pulses, which were watered by the winter rainfall in the northwest, river irrigation, residual soil moisture, and artificial water reservoirs ('tanks') in other regions. ${ }^{38}$ As a year-round activity in the alluvial plains - Indo-Gangetic region and Narmada, Tapti, Mahanadi, Godavari, Kaveri, and Krishna river valleys - agriculture must have absorbed a large part of the available workforce. Middle- and long-distance transfers of agricultural produce and subsistence goods probably drove the thriving use of routes and road networks.

The expansion of hydraulic infrastructure suggests much agrarian development from the second century BCE onward. Given the very different environmental and topographical features of the subcontinent, technologies differed among regions. The northern plains saw more canal irrigation dependent on the perennial rivers. In the Deccan, 'tanks' became more common. In Sri Lanka, reservoirs were constructed to create artificial cascades in some regions. ${ }^{39}$ In areas not inundated by perennial rivers, it was the diversification of crops and usage of drought-resistant varieties that intensified agricultural production. ${ }^{40}$

Commercial agriculture also flourished in this period, perhaps as a response to the rising demand for pepper, cotton, nard, and some other products outside the subcontinent. By the first century CE, they were marketed and exported in massive

36 Murphy and Fuller 2017, 6.

37 Murphy and Fuller (2017) refer to tree crops such as mango, jackfruit, citric fruits etc., along with a variety of cucurbitaceous vegetables being grown in the subcontinent.

38 Petrie and Bates 2017, 89; Murphy and Fuller 2017.

39 For a discussion on the development of hydraulic infrastructure and role of different actors in different regions, see Dwivedi, ch. 10, VI.1, this volume.

40 For a bibliography on the issues of agricultural intensification through various techniques, Kingwell-Banham 2019, 6487-6488. 
quantities to the cities and harbors along the coasts of the Arabian Sea and the Mediterranean, as is well-known from the Periplus Maris Erythraei and other sources. It is interesting to note, however, that each of these products has its own methods and ecological niches of production. For example, spices were grown above all in the highlands and mountainous areas of the Malabar region dependent on seasonal rainfall. The traditional knowledge of foraging combined with swidden agriculture ensured the production and processing of spices before they were ready for transportation..$^{41}$ If we can believe the author of the Periplus, pepper was grown most abundantly in an area called Kottanarike, probably identical with Tamil Kuttam or Kuttanātu, located in the wetlands on the foothills of the Western Ghats. ${ }^{42}$ Cotton, another important commercial crop, was produced in the western Deccan in the water-retentive black soil, regur. The allied industries related to processing cotton and weaving also thrived alongside the increase of its cultivation. Nard, or spikenard, was another plant-based commodity exported to the Mediterranean. ${ }^{43}$ Though it grew in the Himalayan mountains of north India, it was called "Gangetic nard" in Graeco-Roman sources because it was available at the riverine ports along River Ganga first, and then transported to other coastal ports in the Western Ghats. We must also consider the commercial cultivation of coconut trees for the production of coir, which is required for the building of ships in the stitched-boat tradition. ${ }^{44}$ These boats were particularly noteworthy to foreign observers and were most closely associated with long-distance trade. Chakravarti relates the donation of 32,000 coconut saplings to the monastic community at Nasik for the commercial investment in the production of coir in the first century CE. ${ }^{45}$ The great variety of production centers shows the great connectivity of the Indian subcontinent, both in terms of infrastructure and communication relevant for concentrating these products in export harbors.

\section{III.2 Craft Production and Artisanal Goods}

Archaeological remains from the third century вСE onward show a substantial increase in a large variety of manufactured goods, particularly relief carvings and sculpture, beads, glass, and above all, pottery. There was a great variety of regionally produced pottery, broadly categorized into three types. First, 'glazed ware,' including northern black polished ware (NBPW), black slipped ware (BSW), and russet coated painted ware (RCP). Second, 'grey ware,' variants of which include a variety of rouletted ware (RW) and moldware. Third, 'red ware,' including the red

41 Morrison and Lycett 2013, 132-133.

42 PME 53 with De Romanis 2020, 88-89, for a discussion of the location of Kottanarike.

43 Dalby 2000, 86.

44 Ray 2003, 59-60 for a discussion.

45 Chakravarti 2017, 324-325. 
and black ware (RBW) variants. ${ }^{46}$ The red wares and the RBW go back to the Chalcolithic period and NBPW has been dated to ca. the sixth century BCE. Yet many regional varieties have been found from the third century всE onward.

While the presence of a greater variety of pottery is indicative of increasing economic complexity, it is also an indicator of other economic factors. First, we can identify the movement of fine, polished luxury tableware from the north to the southern regions. NBPW is first found in the middle Ganga valley, but from the third century BCE onward it was also produced in the lower Ganga valley. NBPW was also exported to Sri Lanka and port sites of Wari-Bateshwar in present-day Bangladesh before it moved on to ports of Thailand.${ }^{47} \mathrm{RW}$ shows a similar increase in the extent of its distribution. The epicenter of its production was the lower Ganga valley and the present Gujarat region. From the third century BCE it is found together with NBPW at various sites in southern and central Thailand, in Oman, and many other sites along the Persian Gulf and the Red Sea. ${ }^{48}$ The second notable feature is the imitation of certain pottery types in southern regions. In Tamil Nadu, coarse red and black wares mainly associated with storage are identified as locally produced imitations of the northern varieties. The practice of imitation, including the use of locally available raw materials, shows that there were not just functional but also stylistic takeovers and adaptations. ${ }^{49}$ There was not only an increased demand for pottery for regular use as storage containers, but this demand was also increasingly supplied by local craftsmen.

The production of glass beads is another industry of interest, associated with the hinterlands of coastal regions. ${ }^{50}$ It is argued that glass ingots were imported, melted, and crafted into glass beads in local workshops that used the furnace-winding technique as the most common and simplest method of beadmaking. ${ }^{51}$ More than 35 centers of production have been identified within the subcontinent. The most important centers of glass-bead production were Ahichchatra and Kaushambi in the north, Arikamedu and Karaikadu in the south, and Kolhapur and Nevasa in the Deccan. ${ }^{52}$ Noteworthy is the mention of raw glass as an item of import at the port of Barygaza (Bharuch) and Muziris (Pattanam) in the Periplus. ${ }^{53}$ Certain sites,

46 See Reddy 2015; Tripathi and Singh 2018; Cherian and Menon 2014, 88-95; Lefrancq and Hawkes 2020.

47 Jahan 2012, 209-10.

48 For observations on regional centers of production and long-distance transportation, see Pavan and Schenk 2012; Reddy 2015; Rai et al. 2014.

49 Smith 1999, 117-118.

50 Also, Evers 2017, 168-170 for a discussion and further reference.

51 The furnace-winding method involves the production of glass beads by twisting the glass around a metal rod, and the beads produced by this method are the wound-bead type (Kanungo 2004, 129).

52 Kanungo 2004.

53 PME 48-49, 56 with Casson 1989, 22-23. 
like Arikamedu, may have been production centers for custom-made glass products for Southeast Asian and Chinese markets. ${ }^{54}$

Sculpting and masonry also seem to have experienced a surge from the third century BCE onward. This was connected in large degree to the rise of monastic Buddhism. Visual representations of religious narratives on stone reliefs, friezes, and sculptures were media of storytelling in early Buddhist contexts and developed in close association with monastic settlements. Examples come from various sites at Gandhāra, Sanchi (Madhya Pradesh), Bharhut (Madhya Pradesh), Amaravati (Andhra Pradesh), Nagarjunakonda (Andhra Pradesh), Kanaganahalli/Sannati (Karnataka), as well as the rock-cut caves in Maharashtra and hundreds of other sites across the subcontinent. ${ }^{55}$ Yet the increase in masonry and sculpture was not just related to representations of Buddhist deities. Many of the sites, such as Mathura, exhibit Hindu, Jaina, and Buddhist religious arts in conjunction. ${ }^{56}$ The pan-Indic phenomenon is indicative of networks of knowledge and communication, as well as the mobility of artisans skilled in their craft. The development of construction work and sculpture is also connected with the development of settlement and urbanization to which we turn next.

\section{III.3 Development of Cities, Ports, and Hinterland}

The development of urban centers can be seen as an increase in the productive capacity of the immediate hinterlands of settlements, as well as their connectivity with more distant centers of production. The focus here is the growth of cities as centers of consumption and redistribution, and questions of physical connectivity are discussed in the next section.

Archaeological, epigraphic, and literary sources offer combined evidence for the growth of urbanism throughout the subcontinent. Yet cities grew for different reasons. Pātaliputa, Taxila, and Madurai are examples of fortified administrative centers. Korkai, Bharuch, Pattanam, and Arikamedu grew as nodes of long-distance trade networks. While others, such as Sanchi, Varanasi, and Sarnath, experienced growth as religious centers.

Most of the cities in the northern plains had a long history of continued occupation and saw steady expansion from the first millennium BCE onward. ${ }^{57}$ In the early historic period, there is no evidence of royal city foundations and colonization as is known from Hellenistic Asia. ${ }^{58}$ Royal patronage and fiscal privilege do

54 Borell 2010, 137.

55 For a discussion and bibliography, see Dwivedi, vol. 1, ch. 10.A, 433-435. See also Morris, ch. 13, IV.3, this volume.

56 Singh 2004.

57 Chattopadhyaya 2003, 50-55.

58 Kosmin 2014, 46. 
not seem to account for the prosperity of these cities. However, in the western Deccan a change in settlement patterns is visible around the second and first centuries всE. There was an increase in the number of settlements and also a change in the nature of material remains. During this period, market centers and cities along trade routes in the western Deccan emerged, ${ }^{59}$ and we also know about a few Sātavāhana rulers who founded cities. ${ }^{60}$ In the eastern Deccan and further south, settlement culture is identified with the megalithic phase starting from about 1000 BCE, which continued till $300 \mathrm{CE} .{ }^{61}$ In the early centuries CE, however, inscribed sherds, iron tools and weapons, gold ornaments, and processed grain from both burial and settlement zones indicate greater connectivity of the settlements with regional as well as distant sites. ${ }^{62}$ Yet the sites remained small. Those classified as large settlements were about five ha in extent, capable of supporting a population of about $1,000 .^{63}$

By the early historic period, most of the important cities had well-connected satellite settlements. The urban center was not marked by a productive hinterland, but by being a part of other well-connected clusters of site. For example, Mathura has been identified as a 'settlement locality' with a series of urban sites forming an urban microregion. ${ }^{64}$ Varanasi, Sanchi, Anuradhapura, Tirunelveli, and Tungabhadra valley also exhibit connected satellite settlements that formed an urban cluster. ${ }^{65}$ It is believed that this clustering of sites and their connectivity allowed the emergence and sustenance of villages with specialized craftsmen and servicemen. There were villages of ivory carvers (dantakāragrāma), centers for textile production, and for the maintenance and upkeep of a monastery. ${ }^{66}$ References to such settlements are found quite often in literary sources, and it would not be wrong to conclude that such specialized settlements survived and operated when functioning as a cluster for their mutual needs. Specialized corporate and professional associations also operated within these regions. The phenomenon of clustering of sites goes beyond what the archetypical urban zones of the north and the western Deccan. Even the settlements of the megalithic sites show clustering in southern re-

59 Ray 2006a, 116-117.

60 For example, the foundation of Vijayapūri (Nagarjunkonda) is credited to Vijaya Sātakarṇi, Navanagara was probably founded by Pulumāvi, and Vaijayanti (modern Vanavasi in Karnataka) was founded by Cuṭukulānanda Sātakarṇi. Mirashi 1981, pt. 1, 121.

61 The megalithic phase is marked by the iron-using communities who raised monuments of stones that were often of sepulchral nature.

62 For further references, see Dwivedi, vol. 1, ch. 10.A, 447-448.

63 Ray 2006a, 114-115.

64 Chattopadhyaya 2003, 68-69.

65 Rea 1904; Coningham et al. 1999; Shaw and Sutcliffe 2003; Basant 2012; Bauer 2015.

66 See Dwivedi, ch. 5, VII, this volume. For 'slave' settlements with primary function of taking care of monasteries, see Schopen 1994. 
gions. In a study of settlements around iron ore zones in Tamil Nadu, about 70 sites were found within a distance of up to twenty $\mathrm{km} .{ }^{67}$

The late first and early second centuries CE saw a great increase in coastal sites and pottery all along the Bay of Bengal and the Arabian Sea. ${ }^{68}$ Many of the coastal sites are identified as port cities that must also be understood in their regional context. Inland cities, such as Pāțaliputra, Mathura, Madurai, Varanasi, Anuradhapura, and others, are all situated along navigable rivers with connectivity to the coastal zone areas by fluvial routes. ${ }^{69}$ South Asia has four coastal zones that were connected to the subcontinent: the western coast of India, with centers in modern-day Gujarat and Maharashtra; the eastern coasts opening into the Bay of Bengal; the Malabar coast and the south of Tamil Nadu, and closely connected to the latter; the coastal ports of Sri Lanka. In earlier scholarship, the development of larger ports along these coasts was explained by their role in Roman trade. However, with Begley's study of regional pottery styles and the growth of Arikamedu, the theory of Indian coastal ports as standalone Roman emporia was overhauled. Begley was able to contextualize the port of Arikamedu within a series of interconnected settlements along the Gingee River. ${ }^{70}$ Following her pioneering work, other port sites were studied with an emphasis on their regional contexts and fluvial connection to the hinterlands. Most of the important ancient ports were located at the mouth of river estuaries rather than on the coast directly. The best examples are Barbarikon on the Indus River, Barygaza (Bharukaccha) in the estuary of the Narmada River, Muziris (Pattanam) at the Periyar River, Poompuhar at the Kaveri Delta, Tamralipti at the mouth of the Ganga River, Godavaya at the delta of Walawe Ganga, among many others. ${ }^{71}$ The location of ports and harbors on riverine routes makes them part of a history of growing connectivity.

\section{III.4 Routes and Connectivity}

Ethno-archaeological approaches and Indic literary sources have long referred to the traditional routes traversed through time immemorial. However, it is only in the early historic period that we find references to established routes. Long-distance travel within early South Asia went along large and smaller inland routes, rivers, and cabotage along coastlines. Together, they formed a complex network of highways and arterial roadways. ${ }^{72}$

67 The author further explains that the sites appearing in the vicinity of iron ore are only 40 percent, rest are farther and yet have yielded iron objects. For a detailed discussion, see Moorti 1994, 16, 108; Ray 2006a, 114-116.

68 Ray 2006b; 2018.

69 See Dwivedi, vol. 1, ch. 3, map 1.

70 Begley 1983.

71 Deloche 1983; 1994, 5-128.

72 Dwivedi, vol. 1, ch. 3, map 1. 
Despite the undeniably local origins of routes and roads, much imperial effort was devoted to improving roads for the movement of armies, people, and tributes. The second Major Rock Edict of Aśoka announces that "on the roads trees were planted, and wells were caused to be dug for the use of cattle and men."73 The seventh pillar edict mentions wells and rest houses built in short intervals. ${ }^{74}$ Moreover, royal roads (basilikai hodoi) were a notable feature that Greek authors observed when writing about India. Strabo, based on earlier Hellenistic geography and ethnography, reports a royal road of 10,000 stadia that ran from the northern regions to Pataliputra. ${ }^{75}$ Pliny gives the length of a route from Peucolatis on the bank of the Kabul River via Taxila to the mouth of the Ganga by measuring the distances from station to station. ${ }^{76}$ Strabo mentions magistrates who built roads and set up pillars at distances of 10 stadia. ${ }^{77}$ The equipping of such roads with supply stations and distance markers may have been modeled on the Achaemenid royal road system, or was simply a typical imperial strategy. In any case, well-equipped, publicly supervised roads embedded in clustered settlements and cities were indispensable means of drawing together people, revenue, and armies in an ecological context where large stretches of territory were unsuitable for urbanization and travel.

Routes filled a large variety of functions - they played a role in administration and trade, but also formed semiautonomous regional centers of communication and exchange, and in some places were clusters of religious and cultural activity. ${ }^{78}$

\section{III.5 Monetization}

The first coins, called the punch-marked coins (kärșāpana) in the northern parts of South Asia, are dated to the sixth century BCE, and minted in both silver and copper variations. Each punched symbol seems to have signified the authorization of the coins by different bodies. From about 300 BCE there was a much greater variety, and far greater volumes, of coinage. ${ }^{79}$ From the second century всE onward, coin legends became common. Uninscribed kārșāpaṇa and inscribed coins circulated together, suggesting that they were mutually exchangeable, or that different coin systems operated side by side.

Various numismatic developments throw light on greater degrees of monetary connectivity from the third century BCE onward. Most regional coins of kārșāpaṇa standard were minted in copper from deposits in the Aravalli Hills, which spread

73 Rock Edict (RE) 2, trans. Hultzsch 1925.

74 RE 7; Neelis 2011, 188-9 for the debatable translation of 'rest houses.'

75 Strabo Geography (Strab.) 15. 1. 11.

76 Such distances were measured by so-called bematists who measured routes by counting steps.

77 Strab. 15. 1. 50.

78 Fussman 1987-1988, 66-68; Thapar 2003, 196; Neelis 2013, 14.

79 See also Dwivedi, ch.10, III.1; Morris, ch. 9, II.3, this volume. 
into the mineral-rich plateaus of central India and the modern state of Bengal. ${ }^{80}$ The Indo-Greeks, by contrast, minted coins in silver that may have been acquired from more distant sources. ${ }^{81}$ The Sātavāhanas, furthermore, issued their coins in lead, along with potin and copper. It is possible that the lead for these coins was not only mined locally, but also imported. The Periplus mentions lead and copper imports in bulk at Barygaza (Bharuch). ${ }^{82}$

Greek drachms and Indic/Graeco-Indian kārșāpaṇa started to circulate together from the time of Indo-Greek presence in the northern region, as we said above. The use of bilingual and biscriptual coin legends, moreover, is indicative of monetary zones in which multiethnic and multilingual communities lived and interacted. There were also stylistic changes, such as the use of a king's portraits on the coins as a result of interaction and conflict with the Greek in the northwestern region. At the same time, regional political confederacies (janapadas of the Yaudheyas, Ārjunāyanas, Kuṇinda, and others), and monarchies (Mitras, Pāñcāla, Daśārṇa, Śibis, Sātavāhanas) issued and counter-struck coins to establish their own political identities, suggesting a greater interest in self-definition vis-à-vis others. ${ }^{83}$

The southern parts of the subcontinent also experienced a great influx of nonregional coins. Examples are the northern punch-marked coins that spread further south from the second century BCE onward, and Roman silver denarii and gold aurei entering the southern subcontinent in some quantity from the first century CE onward. Whether the nonlocal coins functioned as media of exchange has been debated. ${ }^{84}$ While they certainly acted as stores of value, their use as currency is uncertain. The extra-monetary functions of these coins might be emphasized by their being found in stūpa deposits and other ritual contexts. ${ }^{85}$ It is important to note that in the subcontinent other items still functioned as money, while not all coin-like objects had monetary function. ${ }^{86}$

\section{III.6 Elitism and the Rise of Middling Occupational Groups in Urban Spaces}

The administrative posts of the Mauryan state created economic opportunities for a growing 'middling group' in the ancient context. ${ }^{87}$ Epigraphic sources, too, hint at

80 Shrivastva 1999, 174-177.

81 It was long thought that there were few or no silver resources in India, making most silver items, including coins, foreign imports. Yet recent studies of Dariba and Agucha in the Aravalli Hills of Rajasthan have revealed that there were mines yielding argentiferous lead suitable for the extraction of silver (Craddock 2014, 1088).

82 PME 49, 56, 60.

83 See also Bhandare 2006; Dwivedi, vol. 1, ch. 10.A, 452-456; ch. 10, III, this volume.

84 Cobb 2018, 250-271 for a summary of evidence and discussions.

85 Dwivedi, vol. 1, ch. 10.A, 453-458.

86 For a discussion on this issue, Dwivedi, vol. 1, ch. 10.A, 456-458.

87 Smith 2018. 
an elaborate administrative apparatus that hired a number of officers employed as skilled workers and in managerial positions at various levels. The presence of a complex and multitier bureaucratic machinery under the Mauryas can also be gleaned from the fragments of the Indica of Megasthenes, the Macedonian ambassador to the court of Candragupta Maurya. ${ }^{88}$ Epigraphic sources relating to the Sātavāhanas, King Khāravela, and other unattributed polities provide evidence for similar occupational specializations in other parts of the subcontinent. ${ }^{89}$ In the Arthaśāstra, officers are recommended to be paid regular salaries that created a ranked society depending on the resources at the disposal of officials. The highest officials were those closest to the king's office and received 48,000 panas a month. ${ }^{90}$ Successive salaries were halved with each lower office. The lowest monetary compensation was $1 \frac{1 / 4}{4}$ pana monthly, along with a ration and some share in produce depending on the nature of work. ${ }^{91}$ The pay scale of the Arthaśāstra does not perhaps reflect real salaries, but the idea of status depending on occupation and the scale of income might not have developed in a political vacuum.

Occupation in the royal administrative hierarchy was perhaps the most important means of attaining, or confirming, social status. Yet there were other means of expressing that one was in a high social position. Monetary donations and sponsorship of art for Buddhist monastic communities are among the most conspicuous. They are evidence not only for the spending capacity of particular occupational groups, but also for the significance attached to the display of the financial means that an occupation entailed. The importance of occupation and spending capacity is clear from the large number of donative records by individuals who identify themselves by their professions, such as merchants, bankers, caravan leaders, and goldsmiths, to name but a few.

The growing degree of social mobility in urban contexts is also evident from some literary sources. ${ }^{92}$ We find compilations of treatises or guidebooks on how to train oneself as a successful member of the urban elite. A text like the Kâmasūtra of Vātsyāyana, for example, provides a 'cultural grammar' expressing the social expectations and ideals that a successful urban dweller was to fulfill. ${ }^{93}$ This included personal grooming and proper adornment with luxury items.

In this context, the growing circulation of luxury tableware is noteworthy. The expansion of demands for the specially glazed NBPW in the Ganga valley is attribut-

88 Thapar (2013, 119-172) discusses the complexity of administrative machinery under the Mauryas.

89 Mirashi 1981, pt. 1, 119-128; Kant 2000, 63-64; Sastri 1925, respectively.

$90 K A$ 5. 3. 3; for a note of caution using these figures at face value, Chattopadhyaya 2003, 218.

91 The highest paid offices are of the sacrificial priest, the preceptor, the minister, the chaplain, the commander-in-chief, the crown prince, the king's mother, and the crowned queen (KA 2. 24. 28-29).

92 Kaul 2011.

93 Pollock 1985. On the Kāmasūtra, see Dwivedi, vol. 1, ch. 10.A, 431-433. 
ed to the Mauryan period; ${ }^{94}$ Roman glass tableware found in the Pattanam excavations is dated to the early centuries $\mathrm{CE} ;{ }^{95}$ and the red-on-golden and red-on-red slipped wares start to occur so frequently in the Swat Valley during the third century CE that Olivieri has called "fashion ware." 96 The movement of these luxury items was made possible by complex networks.

\section{Networks and Movement of People and Goods}

"Pull towards the coast" is a phrase used by Chakravarti to describe the phenomena of inland settlements experiencing greater connectivity with coastal regions. ${ }^{97}$ Chakravarti's notion is based on the observation of the rise of numerous port cities in coastal regions from the first century CE onward. Moreover, Ghosh has explained this phenomenon by contextualizing the port cities in their hinterland. She suggests that the growth of hinterland in immediate areas as centers of production sustained the port cities as centers of trade. Apart from the immediate hinterland and their local production centers, the ports also received supplies from more distant regions, which she identifies as discontinuous hinterlands. An example of the former is Barygaza (Bharuch) at the mouth of the river Narmada with production centers for beads, cotton, and gemstones. In contrast, the port of Barbarikon at the mouth of River Indus was a port city serving as a terminus for transit trade without a significant production center. Barbarikon, rather, had an extended and perhaps discontinued hinterland from where goods like Chinese pelts, indigo, nard, lapis lazuli, and a few others were exported. ${ }^{98}$ Understanding how people and goods moved through the hinterlands is thus essential to understanding the functioning of port cities.

\section{IV.1 Caravan Groups and Cooperatives As Movers}

The state maintained roads as well as inland and coastal ports, ${ }^{99}$ but unlike in Han China, we are not aware of any restrictions on the use of roadways by private travelers. ${ }^{100}$ While the state was involved in the transport of certain goods, the majority of

\footnotetext{
94 Rai et al. 2014.

95 Cherian 2011.

96 Olivieri 2017.

97 Originally, the phrase was used by Chakravarti (2011) in context of early medieval economic processes. However, in his other writings he has observed and explained the factors and contexts of the "pull" even in the early historical times. See also Chakravarti 2017; 2020.

98 Ghosh 2014.

99 For development of infrastructure, see Dwivedi, ch. 10, VI, this volume.

100 In China, certain lanes were strictly reserved for the emperor, Leese-Messing, ch. 11, VI.2, this volume.
} 
transport activities can be attributed to private individuals, merchants, and trading organizations. Retail and reselling did not earn great revenues for the state, but toll taxes (vartanī) and escort charges (ātīvāhika) are mentioned in the Arthaśāstra as important sources for state income. ${ }^{101}$ The importance attributed to privately organized transport becomes clearer with the prevalence of references to caravans in the jätaka texts. Caravans of merchants moved seasonally. ${ }^{102}$ Monks had rock-cut caves dedicated to their seasonal halts during the monsoon season.

The leader of the caravan, sārthavāha, was responsible for arranging the security of the caravans, ensuring the availability of fodder for animals, and keeping track of navigation and the route of transport. ${ }^{103}$ Sārthavāhas are often described as leading a large number of wagons from the eastern regions to the western limits (pubbāntaparānta in Prākrt). ${ }^{104}$ There were trails of as many as 500 bullock carts loaded with commercial products, frequently composed of shared cargos. Shared cargos are a common phenomenon in antiquity when people preferred to move in bigger caravans, as this reduced the risks involved in traveling long distances. Early historic pottery remains have been found with graffiti marks and inscriptions that have been identified as post-fire markings distinguished from a potter's marks. These markings in the form of symbols and names were likely marks of ownership for easy identification of the merchandise in a composite cargo. ${ }^{105}$

Alongside ox-drawn carts, animal porterage must have formed an important part of the caravan trade. ${ }^{106}$ Though ancient sources say little on the subject, comparative studies and references in the travel accounts of later periods suggest that long-distance transport involved a differentiated system of animal (and human) porterage. The most commonly used animals were pack-oxen in the tropical parts of the subcontinent, while the dromedary performed the same role in more arid areas. Additionally, mules and donkeys took over in higher altitudes. Horses and elephants may have been used occasionally for long-distance commodity transportation, but their cost of maintenance and strength were disproportionate to the requirements of transportation. ${ }^{107}$ To judge again from comparative studies, there

$101 K A$ 2. 16. 18.

102 A long-distance traveler was expected to be away from home for months. Wives are often recommended to wait for a couple of years, in some cases as long as twelve years, before remarrying (KA 3. 4. 24-27).

103 The jātakas are replete with the importance of sārthavāhas. In many stories they are the protagonists, the 'potential Buddha' (Bodhisattva). For discussion on the jātakas as a source of history, see Dwivedi, vol. 1, ch. 10A, 433-435.

104 Chakravarti 2007b, 43.

105 Coningham et al. 1996, 89-92.

106 The Arthaśāstra discusses in detail the guidelines for acquisition and maintenance of porting animals and beasts of burden, including oxen, horses, donkey, camels and mules (KA 2. 6. 7; 2. 15. 50-54; 2. 29).

107 Deloche 1993, 236. 
were specialized groups that raised oxen for hire. While there also were merchants traveling with their own animals, a large part of the caravan animals was provided by nomadic, semi-nomadic, and other pastoral groups specializing in the breeding and lending of animal for porterage. Also, peasants in the countryside lent their animals for the transport of goods to regional markets during slack periods. ${ }^{108}$

\section{IV.2 Ceramic Evidence of Storage and Transport}

In comparison to the Graeco-Roman world, where we know of large amounts of grain being transported from long-distance to large cities, South Asia experienced a more regional and multifocal distribution of resources. Notably, there are hardly any recommendations for concentrating all in-kind taxes in a single core. The Arthaśāstra recommends to the 'superintendent of storehouses' (koșțhädhyakșa) to ensure building regional storehouses (koșțhāgāra) and warehouses (bhaṇ̣̂āgāra) of different goods. Regional storehouses allowed for better management during times of natural calamities and food shortages. A seal from the Bengal region dated to the period of our concern corroborates the presence of such warehouses. ${ }^{109}$

The large number of ceramic finds in archaeological contexts are not just material evidence for large-scale craft production, but also for the importance of storage facilities. Storage facilities are often identified through the concentrations of pottery at a higher-than-normal density. One of the most discussed sets of ceramic studies comes from the site of Pattanam (Kerala), possibly Muziris. A very large number of Indian pottery (99 percent of all finds), together with Roman amphorae and Parthian torpedo jars (less than one percent of the finds), have been interpreted as the storage site near a littoral port. ${ }^{110}$

Smaller assemblages of foreign ceramics have been taken to be the storage containers of travelers for personal consumption. The discoveries of Mediterranean pottery in India and that of Indian potteries in the Arabian Gulf and the Red Sea areas represent diaspora communities for whom commodities from their respective place of origin were transported. The presence of Mediterranean diaspora communities along the Malabar coast was identified by the presence of foreign pottery by Tomber and that of Indians in the Arabian Gulf by Reddy and Pavan and Schenk. ${ }^{111}$

\section{IV.3 Markets and Their Operation}

Markets were important nodes in widespread networks of exchange. The market system in early India can be structured into various levels, starting from local vil-

108 Deloche 1993, 226-254.

109 Sircar 1965, 82-83.

110 For a discussion on the pottery finds at Pattanam, see Cherian 2015.

111 Tomber 2007; 2009; Reddy 2016; Pavan and Schenk 2012. For a brief discussion on developments in the study of early historic potteries see Dwivedi, vol. 1, ch. 10.A, 448-451. 
lage-level markets (āpaṇa), market centers in cities (nargara/pura), and port cities (velākula, pattana, and panyapuțabhedana), as well as monastic markets and seasonal fairs. ${ }^{112}$ There were also transactions, such as gateway sales, that did not take place in a marketplace, but were nevertheless part of the market system. ${ }^{113}$ Unfortunately, evidence for the location of markets is rare. However, we can discern the structure and functioning of the market in certain scenarios. I will discuss the role of the state in organizing markets, especially in urban contexts, the role of nonurban markets, and some aspects of the organization of private trade.

\section{IV.3.1 City Markets and the Role of the State}

Greek visitors observed that cities did not have just a single and central marketplace. ${ }^{114}$ Market streets (äpaṇa-rathy $\bar{a}$ and āpaṇa-vithī) are prominent features of cities in many narrative texts in the Hindu, Buddhist, and Jaina traditions. ${ }^{115}$ We also learn of private residences with 'interior shops' (antarāpaṇa), which were both sites of exchange and workshops. ${ }^{116}$ Shops for particular products were concentrated in certain parts of the city with streets named after the commodity. ${ }^{117}$

Normative texts tend to emphasize state regulation of marketing sites. Dedicated spaces for market exchange and quarters for merchants within the city walls are important parts of city planning in the Arthaśāstra. ${ }^{118}$ The state's role in organizing spaces of exchange was clearly not just for the sake of facilitating exchange, but for easy taxation, the regulation and surveillances of merchants, and checks on fraudulent trading practices as well. Transactions (kraya-vikraya) are one of the main sources of tax income for the state in the Arthaśāstra. Other than the 'director of trade' (panyādhyakșa), two other officials, 'director of tolls and customs' (śulkādhyakșa) and 'superintendent of the marketplace' (samsthādhyakșa) influenced the operations of markets. ${ }^{119}$ Megasthenes also mentions the office of city commissioner (astynomos), regulating market exchange in India. ${ }^{120}$

112 Chakravarti 2001, 24-25.

113 For example, the workshops attached to the residence may not have required items to be brought to the markets and rather the produce was sold at the center of production, as discussed below. Additionally, items bought with agreement for a deferred payment may not have taken place at a public marketplace.

114 Strab. 15. 1. 65.

115 Schlingloff 2013, 11-14.

116 For discussion of terminology, see Schlingloff 2013, 14, n. 10.

117 Thapar 2003, 146. An example is that of the independent goldsmiths and other artisans mentioned in the $K A$ (2. 13. 2), whose workshops (āveśana) are located in a cluster. Olivelle $(2013,537)$ notes that the market street (viśikhā) could refer to 'gold dealers' street.

$118 K A$. 2. 4. 9. Schlingloff (2013) shows how various city plans found in archaeological excavation in the northern region were similar to the descriptions in the $K A$.

119 KA 2. 6 with Chakravarti 2019, 122-124.

120 Strab. 15. 1. 50-52. 
As merchants are seen with suspicion in the Arthaśāstra, it was the state's obligation to repress malpractices - kaṇtakaśodhana literally meaning 'Removal of Thorns' as the title of an entire book in the Arthaśāstra. ${ }^{121}$ The list of malpractice for which the merchants were supposed to be punished includes selling commodities lower in weight and number than agreed; misrepresenting the quality of articles; overpricing to attain profits higher than permitted; adulteration of food and medicinal products; cartelization; and hoarding that affected the prices of commodities. ${ }^{122}$ There are also indications of official price regulations in the city markets. According to the Manusmrti, state officials were supposed to fix the prices of imported commodities by taking into account various expenses of traders - place of production, place of sale, period of storage, and likely profit. Such prices were to be fixed every five or fifteen days by the king publicly. ${ }^{123}$ The Arthaśāstra, in turn, allows local merchants to add no more than a five percent margin, while visiting or nonlocal merchants (āgantunām) were allowed ten percent. To ensure normalcy of prices, officers would restrict the sale of a commodity in one location when there was a glut of a particular commodity. Olivelle suggests that market interventions were aimed at maintaining price stability, controlling wide fluctuations, and eliminating price gouging. ${ }^{124}$

The state was also supposed to prevent price manipulation. Cartels are a wellrecognized problem in the Arthaśāstra, as the members of a cartel, no matter how small, were subject to fines of the highest order (1,000 panas). ${ }^{125}$ Nonlocal merchants, however, were given some protection from being sued by the state in certain monetary matters. ${ }^{126}$ This was perhaps a measure for encouraging traveling merchants who were not familiar with local laws or did not have the support of a guild.

The Arthaśāstra also mentions supervision of seafaring vessels, and ferries at river mouths and across natural and artificial lakes. ${ }^{127}$ The Periplus refers to local fishermen in the king's service guiding seagoing vessels through the narrow delta by the port of Barygaza and up the river to the city. ${ }^{128}$ At Pattanam, remains of a platform made of lateritic rubble and lime with brick lining at the water level have been interpreted as an indicator of a wharf. It was perhaps a ferry site from where the boats might have transferred cargos from the ships moored offshore. ${ }^{129}$

The Arthaśāstra and other normative texts thus suggest a great amount of state intervention in the organization and regulation of markets. Scholars emphasize that

\section{$121 K A$ Book 4.}

122 KA 2. 12. 32; 2. 21. 13; 4. 2. 22; The Manusmrti (MS) 8. 398-400.

123 MS 8. 401-402.

124 Olivelle $(2013,46)$ on $K A$ 2. 16. 1-3; 4. 2. 33.

125 KA 4. 2. 21 with Mehta and Hawk 2018, 12.

$126 K A$ 2. 16.

$127 K A$ 2. 28. 1.

$128 P M E 44$.

129 Gurukkal 2016, 183. 
state intervention aimed to protect consumers. ${ }^{130}$ Indeed, these texts convey a great amount of moral sentiment that did not just serve the interest of the state, but also its subjects. We cannot tell how much these texts were based on, or fed back into, real markets. Yet even if there were urban markets strongly influenced by state control, they were only part of a wider network of marketing facilities.

\section{IV.3.2 Markets Outside Cities and Private Players in Market Spaces}

Religious places of gathering and ceremonial celebrations, such as fairs, played an important role in early India. Ray emphasizes that Buddhist, Hindu, and Jain pilgrim centers emerged as market spaces even before the monuments and temples that survive today were constructed. ${ }^{131}$ The physical spaces around religious centers provided geographical anchors for marketing processes by acting as nodes of exchange and spatial contexts for the provision of credit facilities and knowledge exchange. Ceremonies and religious festivals were important occasions for trade and exchange. Abbott refers to the long tradition of the connection between ceremonial gatherings and market exchange, whereby religious institutions regulated market spaces as well as the moral codes guiding the behavior in market exchange. ${ }^{132}$ Some markets may have been open throughout the year for pilgrims, but others would have varied in size and scale according to season and the demand for certain commodities during festivals for donative and ritual purposes. ${ }^{133}$

Merchants and mercantile organizations worked in cooperation with monastic communities. The Buddhist sites along inland routes, including the rock-cut caves found in the difficult terrain of the Western Ghats, provided shelter for long-distance travelers such as monks, pilgrims, and merchants alike. ${ }^{134}$ Literary sources commonly mention monks and merchants traveling together, and it is possible that cave shelters were also used by merchants during their travels. Moreover, a Buddhist text expresses moral concerns relating to the practice of monks asking merchants to smuggle their items through the customs check to avoid being taxed. ${ }^{135}$

Long-distance traders supplied both urban and monastic centers with large amounts of goods. It is difficult to ascertain whether there was a hierarchical organization of merchants. Yet many sources give glimpses that allow us to speculate a system in which a variety of merchants cooperated and functioned in coordination. The Arthaśāstra recommends providing dedicated spaces for associations and for-

130 Goyal, Goyal, and Goyal 2013; Mehta and Hawk 2018.

131 Ray 2015, 288.

132 Abbott 2010, 80-81.

133 For a brief discussion on pilgrim travels, see Dwivedi, vol. 1, ch. 15, 661-662.

134 For evidence and discussion on connections between the Buddhist sites and trade routes, see Ray 1986; Neelis 2011.

135 The discussion on disputes is preserved in the Mūlasarvastivāda-vinaya, see Pagel 2017, 106. 
eign merchants along the city walls in certain parts of the city, ${ }^{136}$ which could have provided storage spaces for traveling traders and intercity suppliers. Big merchants (śreșthis/sețthis) and associations of traders (śrenis), owned warehouses within the cities where traveling merchants from other cities and from frontiers may have stored their commodities. An example comes from the Akataññu-jātaka, which describes Anāthapinḍaka, a rich sețthi in the city of Śrāvasti, having agreed to offer warehouses for 500 cartloads of goods to be stored and sold by the agents of another merchant from a border region (paccantavāsiko sețți). ${ }^{137}$ The Arthaśāstra implies that merchants used agents to carry out their long-distance travels and transactions. ${ }^{138}$ One type of retailer was a paid laborer who handed over the proceeds of the sale, and in return earned a commission or one-tenth of the profit. ${ }^{139}$ The other type of retailer (pratikretr) bid for the right to sell goods by auction. It is suggested that such auctions were held in the case of imported and wholesale goods. Retailers in this case were no longer agents working for a wage, but entrepreneurs who calculated their own profit. ${ }^{140} \mathrm{~A}$ more detailed understanding of the functioning of markets, however, depends on further research on this topic.

\section{Conclusion}

The economic processes in early South Asia are characterized by a plurality of economic actors operating across diverse landscapes and within a range of political and social institutions and organizational forms. Economic power never truly remained the domain of one actor - cities, elites, kings, monasteries, corporate bodies, nor the state. The functioning and development of various levels of the economy must be regarded as driven by the combination of institutional factors. The cooperation between monastic religious bodies, merchants, and mercantile corporations has been emphasized throughout this chapter. There was also a highly dynamic relationship between state institutions and the institutions of corporate bodies. Even though the prescriptive text of the Arthaśāstra envisions strict regulation of markets and merchants, it also shows that there was a capacity for negotiation. The recommendation by law books to respect the norms and laws of the guilds (śrenidharma), and the nonsalaried position of merchant/banker at the royal court (rājaśreșthi) are further indications of a particular balance between state institutions

136 KA 2. 4. 16.

137 Cowell 1977, story no. 90.

138 The $K A$ mentions agents (vaiyāvrtyakara) through whom commercial transactions could be carried out; $K A$ 2. 5. 18; 3. 12. 25-31.

$139 K A$ 3. 12. 25-30; 3. 13. 27-28; 4. 2. 32. See also Gopal 2001, 932-933.

140 KA 2. 21. 8, 13. with notes by Olivelle 2013, 555. 
and professional corporations. ${ }^{141}$ Rulers also supported Buddhist monks financially while, in return, seeking their support. Important examples include the endeavors of Aśoka to build his imperial power on the establishment of dhammaghoșa (the call of dhamma) and on missions to distant places to spread his faith. Additionally, dedications of shares in revenue from land and ports, and the grants of productive land by the ruling dynasties in the post-Mauryan period strengthened the economic power of the monasteries. ${ }^{142}$

Economic development in early India must therefore be sought in changing structures of various organizations and institutions, as well as their joint political and ideological influence. The growth of cities and agrarian hinterlands was not so much a consequence of state development, but of many local factors as well. The emergence of corporate bodies and new degrees of imperial and interimperial connectivity was related not solely, but importantly, to the expansion of Buddhist monasticism. There were changing economic geographies responding to new levels of regional and interregional demand, yet the coordination of supply was driven by neither market forces nor state intervention, but by interlocking structures that were of apolitical and sub-political nature. At the current state of our knowledge, however, it would be premature to mold these dynamics into more specific models of economic change. The relationship between the state and other organizational forms, and the unique combination of localized and long-distance communication of state and nonstate actors calls for further analysis. There was a unique combination of religious and economic incentives, and a diversity of landscapes that, if developed effectively, had the potential for an increase in productivity at a scale and speed probably unusual for many ancient contexts. More archaeological, numismatic, and epigraphic research is needed to understand the economic patterns of the subcontinent and their effects at different temporal and geographic scales.

\section{References}

Abbott, D. R. 2010. "The rise and demise of marketplace exchange among the prehistoric Hohokam of Arizona." In C. P. Garraty and B. L. Stark (eds.), Archaeological approaches to market exchange in ancient societies, 61-83. Boulder, CO: University Press of Colorado.

Basant, P. K. 2012. The city and the country in early India: A study of Malwa. New Delhi: Primus Books.

Bauer, A. M. 2015. Before Vijayanagara: Prehistoric landscapes and politics in the Tungabhadra Basin. New Delhi: Manohar and American Institute of Indian Studies.

Baums, S. and A. Glass. 2002. "A Dictionary of Gāndhārī." gandhari.org.

Begley, V. 1983. “Arikamedu reconsidered.” American Journal of Archaeology 87.4, 461-468.

141 For more on state and law, see Dwivedi, ch.10, II, IV, this volume. For a discussion on the position of rājaśresțhi, see Chakravarti 2007a; Dwivedi, ch. 4, IV, this volume.

142 Dwivedi, ch. 5, VIII.2, this volume. 
Bhandare, S. 2006. "Numismatics and history: The Maurya-Gupta interlude in the Gangetic plain.” In P. Olivelle (ed.), Between the empires: Society in India 300 BCE to 400 CE, 67-112. Oxford: Oxford University Press.

Borell, B. 2010. “Trade and glass vessels along the maritime Silk Road." In B. Zorn and A. Hilgner (eds.), Glass along the Silk Road from 200 BC to AD 1000, 127-142. Mainz: Verlag des Römisch-Germanischen Zentralmuseums.

Brancaccio, P. 2018. "The Silk Road and the Cotton Road: Buddhist art and practice between Central Asia and the Western Deccan.” In B. Gentino and L. Caterina (eds.), Via della Seta: Percorsi, immagini e cultura materiale. Vol. 2, 59-73. Roma: Scienza e Lettera Editore.

Casson, L. 1989. The Periplus Maris Erythraei: Text with introduction, translation and commentary. Princeton, NJ: Princeton University Press.

Chakravarti, R. 2001. “Introduction.” In R. Chakravarti (ed.), Trade in early India, 1-101. New Delhi: Oxford University Press.

-. 2007a. "Rājaśreșțhī." In Trade and traders in Early Indian society, 102-112. New Delhi: Manohar.

-. 2007b. Trade and traders in early Indian society. New Delhi: Manohar.

-. 2011. "The pull towards the coast: Politics and polity in India (c. 600-1300 CE)." Proceedings of the Indian History Congress 72, 22-42.

-. 2017. "Examining the hinterland and foreland of the port of Muziris in the wider perspective of the subcontinent's long-distance networks." In K. S. Mathew (ed.), Imperial Rome, Indian Ocean regions and Muziris: New perspectives on maritime trade, 307-338. London: Routledge.

-. 2019. "Merchants and state society: Some case studies from early historic period and the 'threshold times' (ca. 600 BC to AD 700)." Studies in People's History 6.2, 119-133.

-. 2020. "The coast vis-à-vis the subcontinent: Interlocking and distinctiveness." In The pull towards the coast and other essays: The Indian Ocean history and the subcontinent before 1500 CE, 75-92. Delhi: Primus Books.

Chattopadhyaya, B. D. 2003. Studying early India: Archaeology, texts, and historical issues. New Delhi: Permanent Black.

Cherian, P. J. 2011. "Pattanam archaeological site: The wharf context and the maritime exchanges." In M. Staniforth (ed.), The 2011 Asia-Pacific Regional Conference on Underwater Cultural Heritage Proceedings. Manila: Museum of Underwater Archaeology Collection.

Cherian, P. J. 2015. "Pattanam represents the ancient urban Periyar river valley culture: 9th season excavation report (2014-15)." Heritage: Journal of Multidisciplinary Studies in Archaeology 3, 739-759.

Cherian, P. J. and J. Menon. 2014. Unearthing Pattanam. Histories, cultures, crossings. New Delhi: National Museum of India; Kerala Council for Historical Research.

Cobb, M. A. 2018. Rome and the Indian Ocean trade from Augustus to the early third century CE. Leiden: Brill.

Coningham, R. A. E., F. R. Allchin, C. Batt, and P. Cheetham. 1999. Anuradhapura: the British-Sri Lankan excavations at Anuradhapura Salagha Watta 2. Vol. 1. Oxford: Archaeopress.

Coningham, R. A. E., F. R. Allchin, C. M. Batt, and D. Lucy. 1996. "Passage to India? Anuradhapura and the early use of the Brahmi script." Cambridge Archaeological Journal 6.1, 73-97.

Cowell, E. B., ed. 1977. The Jātaka, or stories of the Buddha's former births. 6 vols. Oxford: Clarendon Press.

Craddock, P. 2014. "Production of silver across the ancient world.” ISIJ International 54.5, 10851092.

Dalby, A. 2000. Dangerous tastes: The story of spices. Berkeley, CA: University of California Press.

De Romanis, F. 2020. The Indo-Roman pepper trade and the Muziris papyrus. Oxford: Oxford University Press. 
Deloche, J. 1983. "Geographical considerations in the localisation of ancient sea-ports of India." The Indian Economic \& Social History Review 20.4, 439-448.

-. 1993. Transport and communications in India prior to steam locomotion. J. Walker (trans.). Vol. 1, Land transport. Delhi: Oxford University Press.

-. 1994. Transport and communications in India prior to steam locomotion. J. Walker (trans.). Vol. 2, Water transport. Delhi: Oxford University Press.

Evers, K. G. 2017. Worlds apart trading together: The organisation of long-distance trade between Rome and India in antiquity. Oxford: Archaeopress.

Fussman, G. 1987-1988. "Central and provincial administration in ancient India: The problem of the Mauryan Empire." Indian Historical Review 14.1/2, 43-72.

-. 2015. "Kushan power and the expansion of Buddhism beyond the Soleiman mountains." In H. Falk (ed.), Kushan histories: Literary sources and selected papers from a symposium at Berlin, December 5th to 7th, 2013, 153-202. Bremen: Hempen.

Ghosh, S. 2014. "Barbarikon in the maritime trade network of early India." In R. Mukherjee (ed.), Vanguards of globalization: Port cities from the classical to the modern, 59-74. New Delhi: Primus Books.

Gopal, L. 2001. "Agriculture, industry and trade: 600 BC-AD 300." In G. C. Pande (ed.), History of science, philosophy and culture in Indian civilization. Vol. 1.2. The dawn and development in Indian civilization: Life, thought and culture in India (from c. 600 BC to c. AD 300), 912-945. New Delhi: Centre for Studies in Civilizations.

Goyal, P., M. Goyal and S. Goyal. 2013. "Consumer protection law in ancient India." Journal of Human Values 19.2, 147-157.

Gurukkal, R. 2016. Rethinking classical Indo-Roman trade: Political economy of Eastern Mediterranean exchange relations. New Delhi: Oxford University Press.

Hultzsch, E., ed. 1925. Corpus inscriptionum indicarum. Vol. 1, Inscriptions of Aśoka. New Delhi: Director General, Archaeological Survey of India.

Jahan, S. H. 2012. "Maritime trade between Thailand and Bengal." Journal of Fine Arts, Chiang Mai University 3.2, 205-228.

Kant, S. 2000. The Hathīgumphā inscription of Khāravela and the Bhabru edict of Aśoka: a critical study. 2nd ed. New Delhi: D. K. Printworld.

Kanungo, A. K. 2004. "Glass beads in ancient India and furnace-wound beads at Purdalpur: An ethnoarchaeological approach." Asian Perspectives 43.1, 123-150.

Kaul, S. 2011. Imagining the urban: Sanskrit and the city in early India. London: Seagull.

Kingwell-Banham, E. 2019. "Dry, rainfed or irrigated? Reevaluating the role and development of rice agriculture in Iron Age-Early Historic South India using archaeobotanical approaches." Archaeological and Anthropological Sciences 11.12, 6485-6500.

Kosmin, P. J. 2014. The land of the elephant kings: Space, territory, and ideology in the Seleucid Empire. Cambridge, MA: Harvard University Press.

Lefrancq, C. and J. D. Hawkes. 2020. "Accepting variations and embracing uncertainty: Creating a regional pottery typology in South Asian Archaeology." Open Archaeology 6, 269-328.

Mehta, P. S. and B. E. Hawk. 2018. "Economic regulations, competition, and consumer protection in Ancient India." The Antitrust Bulletin 63.3, 316-329.

Mirashi, V. V. 1981. The history and inscriptions of the Sätavāhanas and the Western Kshatrapas. Bombay: Maharashtra State Board for Literature and Culture.

Mishra, A. K. 1992. Trading communities in Ancient India: From earliest times to 300 AD Delhi: Anamika Prakashan.

Mital, S. N. 1995. "Taxation in Kauțilīya Arthaśāstra." Annals of the Bhandarkar Oriental Research Institute 76.1/4, 69-87.

Moorti, U. S. 1994. Megalithic culture of South India: Socioeconomic perspectives. Varanasi: Ganga Kaveri Publishing House. 
Morrison, K. D. and M. T. Lycett. 2013. "Forest products in a wider world: Early historic connections across southern India.” In S. A. Abraham, P. Gullapalli, T. P. Raczek, and U. Z. Rizvi (eds.), Connections and complexity: New approaches to the archaeology of South Asia, 127-142. Walnut Creek, CA: Left Coast Press.

Murphy, C. and D. Q. Fuller. 2017. "The agriculture of early India.” Oxford research encyclopedia of environmental science, 1-36. Oxford: Oxford University Press.

Neelis, J. E. 2011. Early Buddhist transmission and trade networks: Mobility and exchange within and beyond the northwestern borderlands of South Asia. Leiden: Brill.

Neelis, J. E. 2013. "Polyvalent perceptions of the Uttarāpatha in history: Archaeological evidence, epigraphic references and literary demarcations.” In S. Ghosh, S. Ray Bandopadhyaya, S. Basu Majumdar, and S. Pal (eds.), Revisiting early India: Essays in honour of D. C. Sircar, 13-25. Kolkata: R. N. Bhattacharya.

Olivelle, P., trans. 2013. King, governance, and law in ancient India: Kauțilya's Arthaśāstra: A new annotated translation. Oxford: Oxford University Press.

Olivieri, L. M. 2017. “A note on the swat 'fashion ware': Its origin and diffusion.” Ancient Pakistan 28, 105-117.

Pagel, U. 2017. "Nothing to declare: Status, power and religious aspiration in the policies of taxation in ancient India." Medieval Worlds 6, 101-117.

Pavan, A. and H. Schenk. 2012. "Crossing the Indian Ocean before the Periplus: A comparison of pottery assemblages at the sites of Sumhuram (Oman) and Tissamaharama (Sri Lanka)." Arabian Archaeology and Epigraphy 23.2, 191-202.

Petrie, C. A. and J. Bates. 2017. “"Multi-cropping', intercropping and adaptation to variable environments in Indus South Asia." Journal of World Prehistory 30.2, 81-130.

Pollock, S. 1985. "The theory of practice and the practice of theory in Indian intellectual history." Journal of the American Oriental Society 105.3, 499-519.

Rai, S. S., G. K. Rai, A. C. Pandey, and U. C. Chattopadhyaya. 2014. "Geochemical studies of the ancient Indian glazed ware.” Current Science 106.3, 428-434.

Ray, H. P. 1986. Monastery and guild: Commerce under the Sātavāhanas. Delhi: Oxford University Press.

-. 2003. The archaeology of seafaring in ancient South Asia. Cambridge: Cambridge University Press.

-. 2006a. "Inscribed pots, emerging identities: The social mileu of trade." In P. Olivelle (ed.), Between the empires: Society in India 300 BCE to 400 CE, 113-144. Oxford: Oxford University Press.

-. 2006b. "The archaeology of Bengal: Trading networks, cultural identities." Journal of the Economic and Social History of the Orient 49.1, 68-95.

-. 2010. "Coins, seals and sealings at Sanghol.” In H. P. Ray (ed.), Sanghol and the archaeology of Punjab, 166-183. New Delhi: Aryan Books International.

-. 2015. "Trading partners across the Indian Ocean: The making of maritime communities." In B. Z. Kedar and M. E. Wiesner-Hanks (eds.), Expanding webs of exchange and conflict, 500 CE-1500 CE. Vol. 5, 287-308.

-. 2018. "Ethnographies of sailing: From the Red Sea to the Bay of Bengal in antiquity." In M. A. Cobb (ed.), The Indian Ocean Trade in antiquity: Political, cultural and economic impacts, 73-94. London: Routledge.

Rea, A. 1904. "An account of excavation conducted during the year 1903-04." Annual Report of Archaeological Survey of India 1, 18-25.

Reddy, A. L. 2015. "Sourcing Indian ceramics in Arabia: Actual imports and local imitations." Proceedings of the Seminar for Arabian Studies 45, 253-271.

-. 2016. "Archaeology of Indo-Gulf relations in the early historic period: The ceramic evidence." In H. P. Ray (ed.), Bridging the Gulf: Maritime cultural heritage of the western Indian Ocean, 53-78. New Delhi: Manohar. 
Sastri, H. 1925. "Brahmi inscription on a wooden pillar from Kirari." Epigraphia Indica 18, 152157.

Schlingloff, D. 2013. Fortified cities of ancient India: A comparative study. London: Anthem.

Schopen, G. 1994. "The monastic ownership of servants or slaves: Local and legal factors in the redactional history of two Vinayas." Journal of Buddhist Studies 17.2, 145-175.

-. 2004. Buddhist monks and business matters: still more papers on monastic Buddhism in India. Honolulu, HI: University of Hawai'i Press.

Sen, T. 2006. "The travel records of Chinese pilgrims Faxian, Xuanzang, and Yijing: Sources for cross-cultural encounters between ancient China and ancient India." Education about Asia 11.3, 24-33.

Shaw, J. 2007. Buddhist landscapes in central India: Sanchi Hill and archaeologies of religious and social change, $c$. third century $B C$ to fifth century $A D$. London: British Association for South Asian Studies.

-. 2018. "Early Indian Buddhism, water and rice: Collective response to socioecological stress: Relevance for global environmental discourse and Anthropocene studies." In Y. Zhuang and M. Altaweel (eds.), Water societies and technologies from the past and present, 223-255. London: UCL Press.

Shaw, J. and J. V. Sutcliffe. 2003. "Water management, patronage networks and religious change: New evidence from the Sanchi Dam complex and counterparts in Gujarat and Sri Lanka." South Asian Studies 19, 73-104.

Shrivastva, R. 1999. “Mining of copper in Ancient India." Indian Journal of History of Science 34.3, $173-180$.

Singh, U. 2004. "Cults and shrines in early historical Mathura (c. 200 BC-AD 200)." World Archaeology 36.3, 378-398.

Sircar, D. C., ed. 1965. Select inscriptions bearing on Indian history and civilization. 2nd ed. Vol. 1, From the sixth century $B C$ to the sixth century $A D$. Calcutta: University of Calcutta.

Skilling, P. 2008. "Redaction, recitation, and writing: Transmission of the Buddha's teaching in India in the early period." In S. C. Berkwitz, J. Schober, and C. Brown (eds.), Buddhist manuscript culture: Knowledge, ritual, and art., 53-75. London: Routledge.

Smith, M. L. 1999. "The role of ordinary goods in premodern exchange." Journal of Archaeological Method and Theory 6.2, 109-135.

-. 2018. "Urbanism and the middle class: Co-emergent phenomena in the world's first cities." Journal of Anthropological Research 74.3, 299-326.

Thakur, V. K. 1987. "Role of guilds in ancient Indian urban administration (c. 200 BC-c. AD 600): A numismatic study." Journal of the Numismatic Society of India 49, 70-76.

Thapar, R. 2003. The Penguin history of early India: From the origins to AD 1300. London: Penguin Books.

-. 2013. Aśoka and the decline of the Mauryas. 3rd ed. New Delhi: Oxford University Press.

Tomber, R. 2007. "Rome and Mesopotamia: Importers into India in the first millennium AD." Antiquity 81, 972-988.

-. 2009. "Beyond Western India: The evidence from imported amphorae." In R. Tomber, L. Blue, and S. A. Abraham (eds.), Migration, trade and peoples. Part 1: Indian ocean commerce and the archaeology of western India, 42-57. London: The British Academy.

Tripathi, V. and P. Singh. 2018. "Analysing the black polished pottery of proto-historic-early historic India." Current Science 114.11, 2373-2380. 